\title{
Implementasi Fuzzy Menggunakan Mamdani Pada Sistem Pendukung Keputusan Lokasi Pemasangan Iklan Calon Legislatif
}

\author{
Wisnu Syahputra \\ Program Studi Teknik Informatika, Fakultas Ilmu Komputer dan Teknologi Informasi, Universitas Budi Darma \\ Jalan Sisingamangaraja No. 338, Medan, Sumatera Utara, Indonesia \\ Email: wisnusyahputra1304@gmail.com
}

\begin{abstract}
Abstrak-Perkembangan teknologi informasi saat ini membutuhkan informasi yang cepat dan akurat dalam implementasinya. Pemasangan brosur iklan calon legislatif kepada masyrakat yang berkinerja baik dengan dukungan sistem pendukung keputusan merupakan salah satu dari implementasi perkembangan teknologi informasi. Penelitian yang menggunakan metode mamdani dalam sistem pendukung keputusan in imenghasilkan sebuah aplikasi sistem pendukung keputusan pemasangan spanduk yang biasa digunakan pada calon legislatif. Kriteria yang digunakan pada sistem pendukung keputusan pemasangan spanduk iklan ini adalah: nama lokasi, unsur strategi, letak lokasi, iklan saingan dan jumlah penduduk. Hasil penelitian ini adalah letak strategi yang terpilih dari beberapa tempat yang memiliki kinerja yang baik yang telah mengikutin seleksi, dan output dari aplikasi tersebut membantu pengambilan keputusan (desician maker) dalam memilih alternatif penentuan lokasi pemasangan iklan berupa spanduk para calon legislatif menggunakan aplikasi web berbasis dekstop.
\end{abstract}

Kata Kunci: Sistem Pendukung Keputusan; Mamdani; Pemasangan Iklan; Pemrograman Web

\begin{abstract}
The development of information technology today requires information that is fast and accurate in its implementation. The installation of prospective legislative advertising brochures that perform well with the support of a decision support system is one of the implementations of the development of information technology. Research that uses the mamdani method in this decision support system produces a decision support system application for installing banners that are commonly used in legislative candidates. The criteria used in the decision support system for installing advertising banners are: location name, strategy element, location location, rival advertisement and population. The results of this study are the location of the selected strategies from several places that have good performance that have followed the selection, and the output of the application helps decision makers (desician makers) in choosing alternatives for the location of advertisements in the form of banner candidates using desktop-based web applications.
\end{abstract}

Keywords: Decision Support System; Mamdani; Advertising; Web Programming

\section{PENDAHULUAN}

Iklan merupakan salah satu kegiatan paling penting yang dilakukan oleh para calon legislatif dalam usahanya memperebutkan kursi dalam pemilihan umum. Tidak ada satu calon legislatif yang mampu bersaing bilamana calon legislatif tersebut tidak mampu menawarkan atau menjual program-program kerja dalam bentuk iklan maupun brosur. Salah satu faktor yang terpenting dalam pengiklanan adalah dengan menyusun strategi pemasangan iklan maupun brosur berupa umbul-umbul. Dalam hal pemasangan iklan ini perlu adanya suatu sistem pendukung keputusan dimana tim sukses yang hendak memasang iklan tersebut bisa dilihat dan dinikmati khalayak ramai. Yang konsisten dengan tujuan pemasaran yang salah satunya adalah dengan melakukan pemasangan iklan di lokasi-lokasi tertentu yang tujuannya untuk meningkatkan daya beli konsumen terhadap produk yang kita pasarkan.

Belakangan ini dengan sampainya tahun demokrasi dalam hal pemilihan umum kepala daerah dan legislatif banyak tim sukses dari partai masing masing mempromosikan dan menjual visi mereka dalam bentuk spanduk dan brosur, akan tetapi jika diamati dalam pemasangan spanduk maupun brosur tersebut sering kita lihat tidak sesuai dengan tempatnya, tidak sesuai dengan pemasangan yang dapat dilihat dari khalayak ramai khususnya masyarakat umum, tidak tahu kepastiannya apakah memang hanya sekedar memasang dan tidak dalam hal mempromosikan, namun dalam hal penulisan penelitian ini bukan membahas tentang demikian melainkan membahas permasalahan tentang pemasangan iklan berupa brosur tersebut supaya dapat dilihant oleh banyak orang. Oleh karena itu perlu adanya suatu pengambilan keputusan dengan ditambah suatu metode, sehingga pemasangan iklan berupa brosur dan spanduk tersebut dipasang sesuai dengan tempatnya. Konsep Sistem Pengambilan Keputusan (SPK) yang berkembang pesat, menimbulkan beberapa metode untuk menciptakan permodelan sebagai sarana pengambilan keputusan dengan kelebihan dan kekurangannya masing-masing. Salah satu metode dalam Pendukung keputusan adalah menggunakan Metode Mamdani yang sering juga dikenal dengan nama Metode Max-Min. Dalam Jurnal Sukandy Martha. Menyatakan metode mamdani sangat baik dipergunakan sebagai metode dalam sistem pendukung keputusan karena memiliki 4 langkah variabel untuk menghasilkan output atau luaran. Dari penjelasan tersebut terlihat bahwa metode Mamdani dapat menjadi solusi dari permasalahan yang dihadapi oleh tim sukses sekarang ini. Dengan mempergunakan metode Mamdani diharapkan tim manajemen yang bertugas dalam memilih lokasi pemasangan iklan dapat bekerja lebih baik dan

\section{METODOLOGI PENELITIAN}

\subsection{Metode Mamdani}

Metode Mamdani sering juga dikenal dengan nama Metode Max-Min. Metode ini diperkenalkan oleh Ebrahim Mamdani pada tahun 1975. Untuk mendapatkan output, diperlukan 4 tahapan: 


\section{TIN: Terapan Informatika Nusantara}

Vol 2, No 8, Januari 2022, Hal 476-482

ISSN 2722-7987 (Media Online)

Website https://ejurnal.seminar-id.com/index.php/tin

DOI 10.47065/tin.v2i8.992

1. Pembentukan himpunan fuzzy

Pada Metode Mamdani, baik variabel input maupun variabel output dibagi menjadi satu atau lebih himpunan fuzzy.

2. Aplikasi fungsi implikasi

Pada Metode Mamdani, fungsi implikasi yang digunakan adalah Min.

3. Komposisi Aturan

Tidak seperti penalaran monoton, apabila sistem terdiri-dari beberapa aturan, maka inferensi diperoleh dari kumpulan dan korelasi antar aturan. Ada 3 metode yang digunakan dalam melakukan inferensi sistem fuzzy, yaitu: max, additive dan probabilistik OR (probor).

4. Penegasan (defuzzy)

Adapun langkah-langkahnya :

a. Metode Max (Maximum)

Pada metode ini, solusi himpunan fuzzy diperoleh dengan cara mengambil nilai maksimum aturan, kemudian menggunakannya untuk memodifikasi daerah fuzzy, dan mengaplikasikannya ke output dengan menggunakan operator OR (union). Jika semua proposisi telah dievaluasi, maka output akan berisi suatu himpunan fuzzy yang merefleksikan konstribusi dari tiap-tiap proposisi. Secara umum dapat dituliskan:

$\operatorname{sf}[\mathrm{xi}] \max (\mathrm{sf}[\mathrm{xi}], \mathrm{kf}[\mathrm{xi}])$

dengan:

$\mathrm{sf}[\mathrm{xi}]=$ nilai keanggotaan solusi fuzzy sampai aturan ke-i;

$\mathrm{kf}[\mathrm{xi}]=$ nilai keanggotaan konsekuen fuzzy aturan ke-i;

Misalkan ada 3 aturan (proposisi) sebagai berikut:

[R1] IF Biaya Produksi RENDAH And Permintaan NAIK

THEN Produksi Barang BERTAMBAH;

[R2] IF Biaya Produksi STANDAR

THEN Produksi Barang NORMAL;

[R3] IF Biaya Produksi TINGGI And Permintaan TURUN

THEN Produksi Barang BERKURANG;

Proses inferensi dengan menggunakan metode Max dalam melakukan komposisi aturan seperti terlihat pada Gambar 3.6. Apabila digunakan fungsi implikasi MIN, maka metode komposisi ini sering disebut dengan nama MAX-MIN atau MIN-MAX atau MAMDANI.

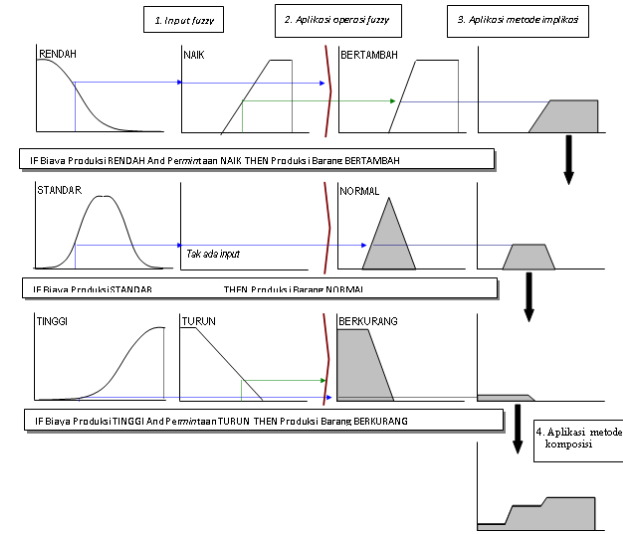

Gambar 1 Komposisi aturan Fuzzy: Metode MAX. Agus Naba, (2009)

b. Metode Additive (Sum)

Pada metode ini, solusi himpunan fuzzy diperoleh dengan cara melakukan bounded-sum terhadap semua output daerah fuzzy. Secara umum dituliskan:

$\operatorname{sf}[x i] \min (1, s f[x i]+k f[x i])$

dengan:

$\mathrm{sf}[\mathrm{xi}]=$ nilai keanggotaan solusi fuzzy sampai aturan ke-i;

$\mathrm{kf}[\mathrm{xi}]=$ nilai keanggotaan konsekuen fuzzy aturan ke-i;

c. Metode Probabilistik OR (probor)

Pada metode ini, solusi himpunan fuzzy diperoleh dengan cara melakukan product terhadap semua output daerah fuzzy. Secara umum dituliskan:

$\mathrm{sf}[\mathrm{xi}](\mathrm{sf}[\mathrm{xi}]+\mathrm{kf}[\mathrm{xi}])-(\mathrm{sf}[\mathrm{xi}] * \mathrm{kf}[\mathrm{xi}])$

dengan:

sf[xi] = nilai keanggotaan solusi fuzzy sampai aturan ke-i;

$\mathrm{kf}[\mathrm{xi}]=$ nilai keanggotaan konsekuen fuzzy aturan ke-i;

4. Penegasan (defuzzy)

Input dari proses defuzzifikasi adalah suatu himpunan fuzzy yang diperoleh dari komposisi aturan-aturan fuzzy. 


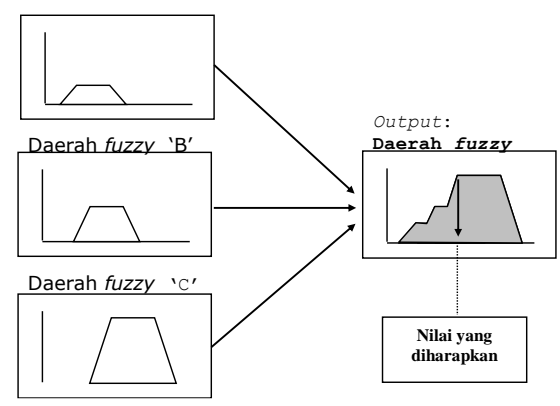

Gambar 2. Proses defuzzifikasi. Agus Naba, (2009)

Ada beberapa metode defuzzifikasi pada komposisi aturan MAMDANI, antara lain:

1. Metode Centroid (Composite Moment)

Pada metode ini, solusi crisp diperoleh dengan cara mengambil titik pusat $\left(\mathrm{z}^{*}\right)$ daerah fuzzy. Secara umum dirumuskan:

2. Metode Bisektor

Pada metode ini, solusi crisp diperoleh dengan cara mengambil nilai pada domain fuzzy yang memiliki nilai keanggotaan separo dari jumlah total nilai keanggotaan pada daerah fuzzy. Secara umum dituliskan:

3. Metode Mean of Maximum (MOM)

Pada metode ini, solusi crisp diperoleh dengan cara mengambil nilai rata-rata domain yang memiliki nilai keanggotaan maksimum.

4. Metode Largest of Maximum (LOM)

Pada metode ini, solusi crisp diperoleh dengan cara mengambil nilai terbesar dari domain yang memiliki nilai keanggotaan maksimum.

5. Metode Smallest of Maximum (SOM)

Pada metode ini, solusi crisp diperoleh dengan cara mengambil nilai terkecil dari domain yang memiliki nilai keanggotaan maksimum.

\section{HASIL DAN PEMBAHASAN}

Dalam pemilihan lokasi pemasangan iklan dengan menggunakan metode Mamdani diperlukan kriteria-kriteria dan bobot untuk melakukan perhitungannya sehingga akan didapat alternatif terbaik, dalam hal ini alternatif yang dimaksud adalah yang layak atau tidak layak sebagai lokasi pemasangan iklan berdasarkan kriteria-kriteria yang ditentukan.

\subsection{Kriteria dan Bobot}

Metode Mamdani dalam prosesnya memerlukan kriteria yangakan dijadikan bahan perhitungan pada proses perankingan. Kriteria yang menjadibahan pertimbangan bagianPemilihan lokasi pemasangan iklanseperti yang ditunjukan pada tabel 1.

Tabel 1. Variabel Bobot

\begin{tabular}{ll}
\hline Nama Variabel & BobotFuzzy \\
\hline Unsur Strategis & Sangat rendah (SR) \\
& Rendah (R) \\
& Sedang (S) \\
& Tengah (T1) \\
& Tinggi (T2) \\
& Sangat tinggi (ST) \\
& Sangat rendah (SR) \\
& Rendah (R) \\
& Sedang (S) \\
Letak Lokasi & Tengah (T1) \\
& Tinggi (T2) \\
& Sangat tinggi (ST) \\
& Sangat rendah (SR) \\
& Rendah (R) \\
& Sedang (S) \\
& Tengah (T1) \\
& Tinggi (T2) \\
Jumlah Penduduk & Sangat tinggi (ST) \\
\hline
\end{tabular}




\section{TIN: Terapan Informatika Nusantara}

Vol 2, No 8, Januari 2022, Hal 476-482

ISSN 2722-7987 (Media Online)

Website https://ejurnal.seminar-id.com/index.php/tin

DOI 10.47065/tin.v2i8.992

Dari tabel 1 di atas makan dapat digambarkan untuk bobot variabel dengan kriteria Fuzzy :

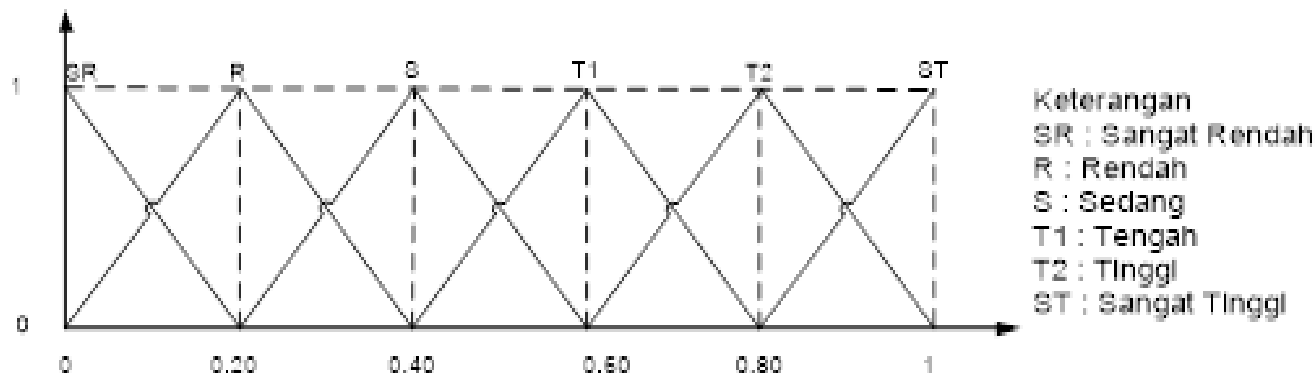

Gambar 3. Bilangan Fuzzy untuk Bobot

Berdasarkan gambar 3, bilangan-bilangan fuzzy dapat dikonversikan ke bilangan crisp. Untuk lebih jelas data bobot dibentuk dalam tabel 2 .

Tabel 2 Bobot

\begin{tabular}{ll}
\hline Bilangan Fuzzy & Nilai \\
\hline Sangat Rendah (SR) & 0 \\
Rendah (R) & $0.20-0,39$ \\
Sedang (S) & $0.40-0,59$ \\
Tengah (T1) & $0.60-0,79$ \\
Tinggi (T2) & $0.80-0,99$ \\
Sangat Tinggi (ST) & 1 \\
\hline
\end{tabular}

Dari tabel 2 maka di dapatkan nilai-nilai semesta yang di letakkan pada tabel 3.

Tabel 3. Variabel Kriteria

\begin{tabular}{lll}
\hline Fungsi & Nama Variabel & Semesta Pembicaraan \\
\hline Input & Unsur Strategis & {$[7,26]$} \\
& Letak Lokasi & {$[49,101]$} \\
& Jumlah Penduduk & {$[0,60]$} \\
Output & Nilai Lokasi & {$[43,83]$} \\
\hline
\end{tabular}

Berdasarkan variabel pada tabel 3, maka disusun domain himpunan fuzzy. Dari domain tersebut, selanjutnya ditentukan fungsi keanggotaan masing masing variabel seperti terlihat pada tabel 4. Berikut adalah perancangan himpunan fuzzy pada penentuan status lokasipemasangan iklan menggunakan kriteria penilaian :

Tabel 4. Tabel himpunan fuzzy

\begin{tabular}{lllll}
\hline \multicolumn{1}{c}{ Variabel } & Himpunan & Domain & Fungsi Keanggotan & Parameter \\
\hline Jumlah Penduduk & Fase 1 & {$[0,12]$} & Bahu Kiri & {$[0 ; 6 ; 12]$} \\
(bulan) & Fase 2 & {$[6,24]$} & Segitiga & {$[6 ; 12 ; 24]$} \\
& Fase 3 & {$[12,36]$} & Segitiga & {$[12 ; 24 ; 36]$} \\
& Fase 4 & {$[24,48]$} & Segitiga & {$[24 ; 36 ; 48]$} \\
Letak Lokasi & Fase 5 & {$[36,60]$} & Bahu Kanan & {$[36 ; 48 ; 60]$} \\
& Rendah & {$[0 ; 75]$} & Bahu Kiri & {$[0 ; 49 ; 75]$} \\
& Sedang & {$[49 ; 101]$} & Segitiga & {$[49 ; 75 ; 101]$} \\
Unsur Strategis & Tinggi & {$[75 ; 124]$} & Bahu Kanan & {$[75 ; 101 ; 124]$} \\
& Ringan & {$[0 ; 13]$} & Bahu Kiri & {$[0 ; 7 ; 13]$} \\
& Biasa & {$[7 ; 19]$} & Segitiga & {$[7 ; 13 ; 19]$} \\
Nilai Lokasi & Berat & {$[13 ; 25]$} & Bahu Kanan & {$[13 ; 19 ; 25]$} \\
& Buruk & {$[0 ; 49]$} & Bahu Kiri & {$[0 ; 43 ; 49]$} \\
& Kurang & {$[43 ; 53]$} & Segitiga & {$[43 ; 49 ; 53]$} \\
& Normal & {$[49 ; 70]$} & Segitiga & {$[49 ; 53 ; 70]$} \\
& Baik & {$[53 ; 82]$} & Segitiga & {$[53 ; 70 ; 82]$} \\
& Sangat Baik & {$[70 ; 124]$} & Bahu Kiri & {$[70 ; 82 ; 124]$} \\
\hline
\end{tabular}

\subsection{Penerapan Metode Fuzzy Mamdani}

Dalam penelitian ini, himpunan fuzzy digunakan untuk menentukan status seorang Lokasi. Himpunan fuzzy tersebut meliputi variabel Unsur Strategis, Jumlah Penduduk dan Letak Lokasi sebagai input, dan nilai sebagai output. Berikut adalah contoh penerapan logika fuzzy dalam menghitung nilai dan menentukan status Lokasi. Lokasi dengan Unsur 


\section{TIN: Terapan Informatika Nusantara}

Vol 2, No 8, Januari 2022, Hal 476-482

ISSN 2722-7987 (Media Online)

Website https://ejurnal.seminar-id.com/index.php/tin

DOI 10.47065/tin.v2i8.992

Strategis 19 dan Letak Lokasi 93 ingin mengetahui nilai dan statusnya.vLangkah penyelesaian dalam penerapan dengan metode Mamdani meliputi :

\section{Langkah 1. Menentukan Himpunan Fuzzy}

Variabel Unsur Strategis telah didefinisikan pada tiga himpuan fuzzy, yaitu: RINGAN, NORMAL, dan BERAT. Setiap himpunan fuzzy memiliki interval keanggotaan, yakni seperti terlihat pada Gambar 2 Berikut adalah gambar tingkat keanggotaan pada variabel Unsur Strategis untuk 19:

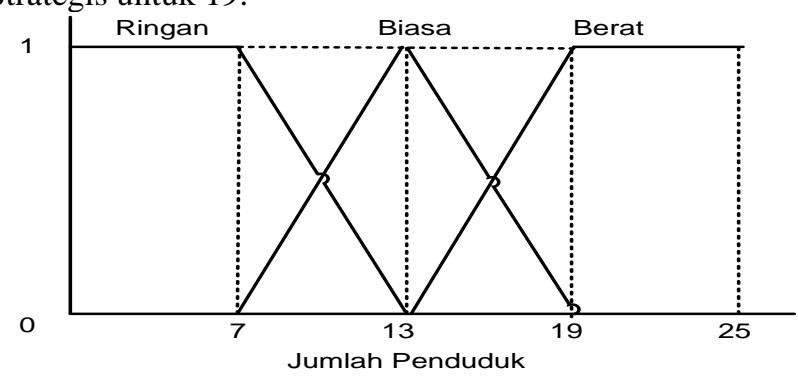

Gambar 4. Grafik Himpunan Fuzzy

Unsur Strategis 19 termasuk kedalam himpunan fuzzy dengan tingkat keanggotaan sesuai fungsi berikut:

$0, \quad x \leq 13$

$$
\begin{array}{cc}
\mu_{\text {Berat }}[X]=x-13 / 6 & 13 \leq x \leq 19 \\
1, & x \geq 19
\end{array}
$$

Sehingga diperoleh :

$$
\begin{aligned}
& \mu_{\text {Ringan }}[19]=0 \\
& \mu_{\text {Biasa }}[X]=0 \\
& \mu_{\text {Berat }}[X]=\frac{19-13}{6}=1
\end{aligned}
$$

yang berarti bahwa, Unsur Strategis orang tersebut dikatakan berat dengan tingkat keanggotaan $80 \%$.

Untuk variabel Letak Lokasi didefinisikan pada tiga himpunan fuzzy, yaitu: rendah, sedang, dan tinggi. Setiap himpuanan fuzzy memiliki interval keanggotaan, yakni seperti terlihat pada Gambar 2 Berikut adalah gambar tingkat keanggotaan pada variabel Letak Lokasi untuk tinggi 93:

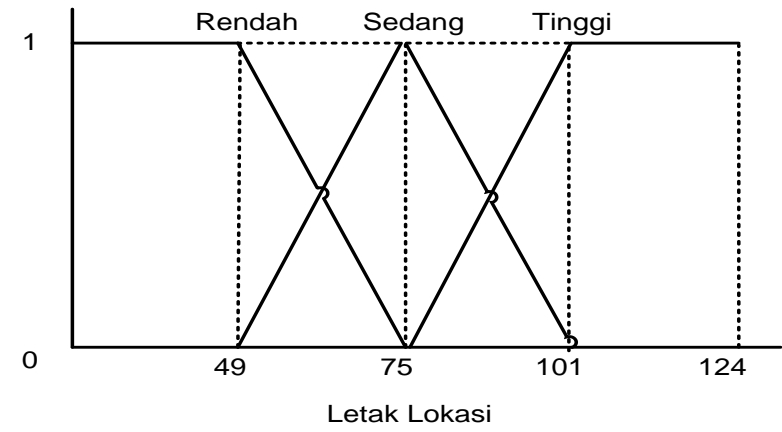

Gambar 5. Grafik Himpunan Letak Lokasi berikut:

Letak Lokasi 93 termasuk ke dalam himpunan fuzzy Sedang dan Tinggi, dengan tingkat keanggotaan sesuai fungsi

$$
\begin{array}{cc}
1, & x \leq 49 \\
\mu_{\text {RENDAH }}[X]=75-x / 26 & 49 \leq x \leq 75 \\
0, & x \geq 75 \\
0, & x \leq 49 \\
\mu_{\text {SEDANG }}[X]=x-49 / 26 & 49 \leq x \leq 75 \\
101-x / 26, & 75 \leq x \geq 101
\end{array}
$$




$$
\begin{array}{cc}
0, & x \leq 75 \\
\mu_{\text {TINGGI }}[X]=x-75 / 26 & 75 \leq x \leq 101 \\
1, & \geq 101
\end{array}
$$

Sehingga diperoleh :

$$
\begin{aligned}
& \mu_{\text {RENDAH }}[X]=0 \\
& \mu_{\text {SEDANG }}[X]=\frac{101-93}{26}=0.30 \\
& \mu_{\text {TINGGI }}[X]=\frac{93-75}{26}=0.54
\end{aligned}
$$

Dari hitungan diatas berarti bahwa, Letak LokasiLokasi tersebut dapat dikatakan sedang dengan tingkat keanggotaan 60\%. Dan Letak LokasiLokasi tersebut juga dapat dikatakan tinggi dengan tingkat keanggotaan $80 \%$.

\section{Langkah 2. Aplikasi Fungsi Implikasi}

Fungsi implikasi yang digunakan dalam proses ini adalah fungsi MIN, yaitu dengan mengambil tingkat keanggotaan yang minimum dari variabel input sebagai outputnya. Berdasarkan aturan-aturan yang sesuai dengan kondisi tersebut, maka diperoleh :

[R8]: Jika Unsur Strategis berat dan Letak Lokasi sedang maka status lebih.

$$
\begin{gathered}
\alpha \text { - }_{\text {predikat }}=\mu_{\text {UnsurStrategisBERAT }} \cap \mu_{\text {LetakLokasiSEDANG }} \\
=\min \left(\mu_{\text {UnsurStrategisBERAT }}(1), \mu_{\text {LetakLokasiSEDANG }}(0.30)\right) \\
=\min (1,0.30)=0.30
\end{gathered}
$$

[R9]: Jika Unsur Strategis berat dan Letak Lokasi tinggi maka status normal.

$$
\begin{gathered}
\left.\alpha-\text { predikat }_{2}=\mu_{\text {UnsurStrategisBERAT }} \cap \mu_{\text {LetakLokasiTINGGI }}(0.54)\right) \\
=\min \left(\mu_{\text {UnsurStrategisBERAT }}(1), \mu_{\text {LetakLokasiTINNGGI }}(0.54)\right. \\
=\min (1,0.54)=0.54
\end{gathered}
$$

\section{Langkah 3. Komposisi Aturan}

Komposisi aturan menggunakan fungsi MAX, komposisi aturan merupakan kesimpulan secara keseluruhan dengan mengambil tingkat keanggotaan maksimum dari tiap konsekuen aplikasi fungsi implikasi dan menggabungkan dari semua kesimpulan masing - masing aturan, sehingga didapat daerah solusi fuzzy sebagai berikut:

$$
\begin{aligned}
& \mu_{s f}=\operatorname{maks}\left\{\mu_{\text {NilaiKurang }}(x), \mu_{\text {NilaiBuruk }}(x)\right\} \\
& =\operatorname{maks}\{0.30,0.54\}
\end{aligned}
$$

Titik potong antara aturan-1 dan aturan-2 adalah ketika $\mu_{\text {NilaiKurang }}(x)=\mu_{\text {NilaBuruk }}(x)$, yaitu :

$$
\begin{aligned}
43-x & =0.3 \\
\Leftrightarrow \quad x & =43-0.3 \\
\Leftrightarrow \quad x & =42.97
\end{aligned}
$$

Ketika nilai $\mu_{\text {NilaiBuruk }}(X)=0.30$, maka dapat ditentukan nilai x sebagai berikut:

$$
\begin{aligned}
& 43-x=0.54 \\
& \Leftrightarrow \quad x=43-0.54 \\
& \Leftrightarrow \quad x=42.46
\end{aligned}
$$

Sehingga didapat fungsi keanggotaan daerah solusi sebagai berikut:

$$
\mu_{\text {Nilai }}=\left\{\begin{array}{lr}
0.67 ; & 13 \leq x \leq 16.33 \\
17-x ; & 16.33 \leq x \leq 16.5 \\
0.5 ; & 16.5 \leq x \leq 18 \\
18.5-x & 18 \leq x \leq 18.5
\end{array}\right.
$$

\section{Langkah 4. Defuzzifikasi}

Langkah terakhir dalam proses ini adalah defuzzifikasi atau disebut juga tahap penegasan, yaitu untuk mengubah himpunan fuzzy menjadi bilangan real. Input dari proses penegasan ini adalah suatu himpunan fuzzy yang diperoleh dari 


\section{TIN: Terapan Informatika Nusantara}

Vol 2, No 8, Januari 2022, Hal 476-482

ISSN 2722-7987 (Media Online)

Website https://ejurnal.seminar-id.com/index.php/tin

DOI 10.47065/tin.v2i8.992

komposisi aturan-aturan fuzzy, sedangkan output yang dihasilkan merupakan suatu bilangan pada domain himpunan fuzzy tersebut. Defuzzyfikasi yang digunakan dalam menentukan nilai adalah dengan metode centroid. Berikut adalah perhitungan defuzzyfikasi dengan metode centroid:

$$
\begin{aligned}
& X=\frac{\int_{13}^{16}(0.67) x d x+\int_{16}^{16.5}(17-x) x d x+\int_{16.5}^{17.5} 0.5 x d x+\int_{17.5}^{18.5}(18.5-x) x d x}{\int_{13}^{16}(0.67) d x+\int_{16}^{16.5}(17-x) x+\int_{16.5}^{17.5} 0.5 d x+\int_{17.5}^{18.5}(18.5-x) d x} \\
& =\frac{\left.\left.\left.\left.\frac{0.67}{2} x^{2}\right]_{13}^{16.33}+\left(\frac{17}{2} x^{2} \frac{1}{3} x^{3}\right)\right]_{16.33}^{16.5}+\left(\frac{0.5}{2} x^{2}\right)\right]_{16.5}^{18}+\left(\frac{18.5}{2} x^{2} \frac{1}{3} x^{3}\right)\right]_{18}^{18.5}}{\left.\left.\left.\left.0.67 x]_{13}^{16.33}+\left(17 x-\frac{1}{2} x^{2}\right)\right]\right]_{16.33}^{16.5}+0.5 x\right]_{16.5}^{18}+\left(18.5 x-\frac{1}{2} x^{2}\right)\right]_{18}^{18.5}} \\
& =\frac{49.52}{3.205}=15.4
\end{aligned}
$$
buruk.

Nilai 15.4 termasuk ke dalam kategori buruk, sehingga berdasarkan perhitungan tersebut status Lokasi adalah

\section{KESIMPULAN}

Dari hasil penelitian dapat disimpulkan sistem pendukung keputusan proses pemasangan iklan dapat ditentukan dengan metode fuzzy mamdani. Sehingga jika kita melakukan penilaian maka akan didapatkan hasil yang tepat untuk penilaian penentuan lokasi pemasangan iklan. Penerapan metod Mamdani maka didapatkan hasil di lokasi mana yang akan dipilih untuk pemasangan iklan calon legislatif. Pendukung keputusan pemasangan iklan dengan metode fuzzy mamdani mampu menentukan hasil keputusan dengan menghitung bobot dari kriteria-kriteria yang sudah ditetapkan hasilnya.

\section{REFERENCES}

[1] Kusrini, Konsep dan Aplikasi Sistem Pendukung Keputusan, Andi Offset, Yogyakarta, 2007

[2] Sutabri Tata, "Sistem Informasi Manajemen", Andi Offset, Yogyakarta, 2005

[3] Efraim Turban, Jay E. Aronson, dan Ting-Peng Liang, penterjemah Dwii Prabantini, Decision Support Systems and Intelligent Systems-7th Ed Jilid 1, Andi Offset, Yogyakarta, 2005

[4] Bin Ladjamuddin Al-bahra, “Analisis dan Desain Sistem Informasi”, Graha Ilmu, Yogyakarta, 2005

[5] Kusumadewi Sri \& Purnomo Hari, Aplikasi Logika Fuzzy Untuk Pendukung Keputusan Edisi 2, Graha Ilmu, Yogyakarta, 2010

[6] Jogyanto HM, "Analisis dan Desain Sistem Informasi”, Andi Yogyakarta 2006

[7] Irwanto Djon, "Perancangan Object Oriented Software Dengan UML", Andi Offset, Yogyakarta, 2007Andi Offset, Yogyakarta, 1995 